\title{
EFFECTS OF VASOPRESSIN ON THE PLASMA CONCENTRATION OF FREE FATTY ACIDS AND IN VITRO OXYGEN CONSUMPTION OF TISSUES OF THE RAT
}

\author{
Shinji IToH, Morio Tsukada, Akimasa Okuno \\ AND Tadashi YoshinaRI \\ Department of Physiology, Hokkaido University School \\ of Medicine, Sapporo
}

It was shown in our previous studies ${ }^{1,2)}$ that the administration of vasopressin caused marked falls in the body temperature and metabolic rate of the rat. Since a significant negative correlationship was found between decrease in the oxygen consumption and increase in the respiratory quotient after administration of vasopressin ${ }^{2}$, the change was inferred to be mainly due to a decreased utilization of fat. According to MIRSKY ${ }^{3-5)}$, injection of posterior pituitary hormone into the dog produced a significant decrease in the plasma concentration of free fatty acids (FFA). The lowered metabolic rate following vasopressin might be, at least in part, attributable to the change in the plasma FFA, because the rate of FFA oxidation has been shown to depend primarily on its plasma concentration ${ }^{6-13)}$. However, contrary to MIRSKY, di GIROLAmo et al. ${ }^{14)}$ reported a slight increase in the plasma FFA concentration after vasopressin in the rabbit. There might be species difference in the response of adipose tissue to the posterior pituitary hormone. In order to elucidate mechanism involved in the hormone action on the metabolic rate, it seems necessary first of all to determine the effect of vasopressin on the plasma FFA concentration and the release of FFA by adipose tissues of the rat. In addition it may be also of interest to find out whether vasopressin affects tissue metabolism directly in reducing fat utilization. The present investigation was undertaken to clarify these problems.

\section{METHODS}

Male Wistar rats, weighing 150 to $250 \mathrm{~g}$, were used throughout the experiments. Synthetic lysine vasopressin and oxytocin (Sandoz) were injected intraperitoneally after the first blood sample had been drawn from the jugular vein through an incision under

Received for publication July 24, 1965

伊藤真次, 塚田守雄, 奥野晃正, 吉成 正 
ether anesthesia. The second sample of the blood was collected 30 minutes after the injection. Norepinephrine in a dose of $200 \mu \mathrm{g}$ per $100 \mathrm{~g}$ body weight was injected subcutaneously 15 minutes after the vasopressin injection; in this case the second sample was obtained 15 minutes thereafter. In control experiments 0.85 per cent sodium chloride solution was given in place of vasopressin. FFA content was determined by the method of TROUT et al.15).

The release of FFA by epididymal fat pads of fasted rats was observed, incubating the tissues in the Krebs-Henseleit phosphate buffer added with bovine albumin at a concentration of $2.5 \mathrm{~g}$ per $100 \mathrm{ml}$ for 2 hours employing a metabolic shaker. When effect of norepinephrine was examined, $10 \mathrm{mM}$ glucose was added together with bovine albumin into the incubation medium. FFA and glycerol in the medium were determined by the methods of Trout et al. and LAMBert and NeIshi ${ }^{16)}$ respectively.

Measurement of oxygen consumption of epididymal white adipose tissue, interscapular brown adipose tissue, liver and diaphragm was made by the Warburg method. In the case of the latter two tissues, $2 \mathrm{mM}$ palmitate with bovine albumin (final concentration of $2.5 \%$ ) was added into the incubation medium of Krebs-Henseleit phosphate buffer.

\section{RESULTS}

Changes in the plasma FFA concentration. Intraperitoneal injection of synthetic lysine vasopressin into fasted rats caused a marked decrease in the plasma concentration of FFA. As shown in TABLE 1, the hormone even in

TABLE 1.

Effect of posterior pituitary hormones on the plasma concentration of free fatty acids in the rat.

\begin{tabular}{|c|c|c|c|c|c|}
\hline & \multirow{2}{*}{$\begin{array}{l}\text { No. of } \\
\text { rats }\end{array}$} & \multicolumn{4}{|c|}{ FFA, $\mu \mathrm{Eq} / 1 \quad($ Mean \pm S. E.) } \\
\hline & & bef ore & after & diff. & $\%$ change \\
\hline Saline control & 15 & $906 \pm 53$ & $916 \pm 58$ & $+6 \pm 31$ & $+1.4 \pm 4.1$ \\
\hline Lysine vasopressin $10 \mathrm{mU} / 100 \mathrm{~g}$ & 6 & $1080 \pm 50$ & $916 \pm 60$ & $-164 \pm 61$ & $\begin{array}{l}-14.8 \pm 5.5 \\
P<0.05\end{array}$ \\
\hline $40 \mathrm{mU} / 100 \mathrm{~g}$ & 9 & $1043 \pm 48$ & $817 \pm 48$ & $-226 \pm 48$ & $\begin{array}{l}-21.1 \pm 3.7 \\
\mathrm{P}<0.01\end{array}$ \\
\hline $100 \mathrm{mU} / 100 \mathrm{~g}$ & 11 & $945 \pm 71$ & $681 \pm 54$ & $-264 \pm 91$ & $\begin{array}{l}-23.4 \pm 7.5 \\
\mathrm{P}<0.01\end{array}$ \\
\hline Oxytocin $40 \mathrm{mU} / 100 \mathrm{~g}$ & 12 & $887 \pm 57$ & $860 \pm 67$ & $-27 \pm 73$ & $-\underset{\mathrm{NS}}{0.7 \pm 9.9}$ \\
\hline $100 \mathrm{mU} / 100 \mathrm{~g}$ & 9 & $992 \pm 54$ & $868 \pm 46$ & $-124 \pm 35$ & $\begin{array}{l}-12.0 \pm 3.3 \\
\mathrm{P}<0.05\end{array}$ \\
\hline Norepinephrine, $200 \mu \mathrm{g} / 100 \mathrm{~g}$ & 8 & $928 \pm 61$ & $1658 \pm 130$ & $+731 \pm 80$ & $\begin{array}{c}+78.2 \pm 6.1 \\
P<0.001\end{array}$ \\
\hline $\begin{array}{l}\text { Lysine vasopressin, } 100 \mathrm{mU} / 100 \mathrm{~g} \\
\text { Norepinephrine, } 200 \mu \mathrm{g} / 100 \mathrm{~g}\end{array}$ & 11 & $1112 \pm 58$ & $1307 \pm 105$ & $+195 \pm 73$ & $\begin{array}{l}+16.7 \pm 6.6 \\
P<0.001 *\end{array}$ \\
\hline
\end{tabular}

* vs Norepinephrine control. 
a dose of $10 \mathrm{mU}$ per $100 \mathrm{~g}$ body weight caused a significant change in it. The concentration decreased 21.1 per cent after $40 \mathrm{mU}$ and 23.4 per cent after $100 \mathrm{mU}$, while no change was observed in control experiment in which saline solution was given in place of vasopressin. The effect of oxytocin was less marked. Injection of synthetic oxytocin in a dose of $100 \mathrm{mU}$ resulted only in a slight decrease in the plasma FFA.

Norepinephrine is known to stimulate the release of FFA by adipose tissues, causing a marked elevation of its plasma concentration. This was confirmed in this experiment. However, in animals which had been treated with $100 \mathrm{mU}$ of vasopressin, the effect of norepinephrine was significantly suppressed (TABLE 1).

Influence of medium concentration of palmitate on the oxygen consumption of tissues in vitro. Decrease in the plasma FFA concentration produced by vasopressin may be involved in the mechanism of the fall of metabolic rate. To ascertain this inference, the influence of FFA concentration in the incubation medium on in vitro oxygen consumption of liver slices and hemidiaphragms. was observed. As illustrated in FIGS. 1 and 2, significant decreases were observed in the oxygen consumption of both tissues as the medium concentration of palmitate reduced.

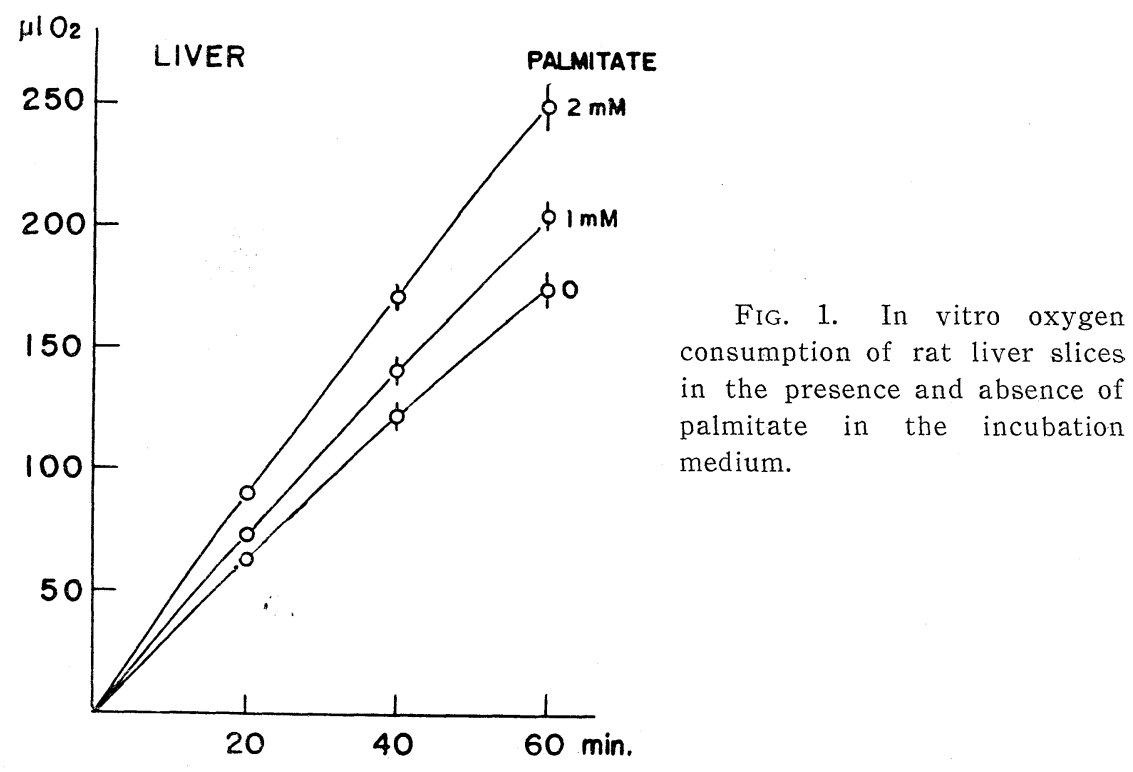

Effect of vasopressin on the release of FFA by epididymal fat pads. An inhibitory effect of vasopressin on the FFA release by adipose tissues might be presumed as a cause of the decrease in the plasma FFA level following ad- 


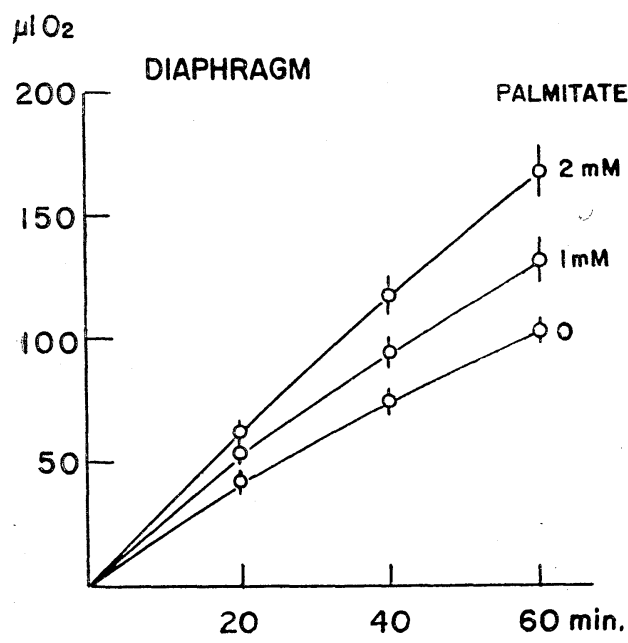

FIG. 2. In vitro oxygen consumption of rat diaphragm in the presence and absence of palmitate in the incubation medium.

ministration of vasopressin. Epididymal fat pads of fasted rats were incubated in the Krebs-Henseleit phosphate buffer added with bovine albumin for 2 hours. As shown in TABLE 2, neither vasopressin nor oxytocin showed any inhibition on the release of FFA at all. Moreover, vasopressin was found not to influence on the lipolytic action of norepinephrine.

TABLE 2 .

Effect of lysine vasopressin on the release of free fatty acids by epididymal adipose tissue in vitro.

\begin{tabular}{|c|c|c|c|c|c|}
\hline & \multirow{2}{*}{$\begin{array}{l}\text { No. of } \\
\text { expt. }\end{array}$} & \multicolumn{2}{|c|}{$\mathrm{FFA}, \mu \mathrm{Eq} / 1$} & \multicolumn{2}{|c|}{ Glycerol, $\mu \mathrm{M} / \mathrm{g}$} \\
\hline & & Mean \pm S. E. & Diff. & Mean \pm S. E. & Diff. \\
\hline $\begin{array}{l}\text { Control } \\
\text { Lysine vasopressin, } 250 \mathrm{mU} / \mathrm{ml} \\
\text { Oxytocin, } 250 \mathrm{mU} / \mathrm{ml}\end{array}$ & 13 & $\begin{array}{l}3.35 \pm 0.37 \\
3.88 \pm 0.46 \\
3.76 \pm 0.36\end{array}$ & 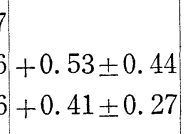 & & . \\
\hline $\begin{array}{l}\text { Norepinephrine, } 0.5 \mu \mathrm{g} / \mathrm{ml} \\
\text { Lysine vasopressin, } 250 \mathrm{mU} / \mathrm{ml} \\
\text { Norepinephrine, } 0.5 \mu \mathrm{g} / \mathrm{ml}\end{array}$ & 9 & $\begin{array}{l}20.52 \pm 0.64 \\
19.15 \pm 1.42\end{array}$ & $-1.37 \pm 0.66$ & $\begin{array}{l}10.74 \pm 0.68 \\
10.14 \pm 0.94\end{array}$ & $-0.60 \pm 0.61$ \\
\hline
\end{tabular}

Effect of vasopressin on the oxygen consumption of tissues in vitro. To find out direct action of vasopressin on the tissue metabolism, the hormone in a concentration of $500 \mathrm{mU}$ per $\mathrm{ml}$ was added into the incubation medium. TABLE 3 shows the results. A statistically significant decrease was observed in the oxygen consumption of the interscapular brown adipose tissue, while that of the epididymal white adipose tissue did not significantly change. The oxygen consumption of liver slices and hemidiaphragms in the presence of 2 $\mathrm{mM}$ palmitate with bovine albumin showed 14.1 per cent and 11.2 per cent 
TABLE 3.

Effect of lysine vasopressin on oxygen consumption in vitro.

\begin{tabular}{|c|c|c|c|c|c|}
\hline \multirow{3}{*}{ Tissue } & \multirow{3}{*}{$\begin{array}{l}\text { No. of } \\
\text { expt. }\end{array}$} & \multicolumn{4}{|c|}{$\mathrm{Qo}_{2} *$} \\
\hline & & \multirow{2}{*}{$\begin{array}{c}\text { Control } \\
\text { Mean } \pm \text { S. E. }\end{array}$} & \multirow{2}{*}{$\begin{array}{l}\text { Vasopressin } \\
\text { Mean } \pm \text { S. E. }\end{array}$} & \multicolumn{2}{|c|}{$\%$ Change } \\
\hline & & & & Mean \pm S. E. & t-Test \\
\hline White adipose tissue & 10 & $14.0 \pm 1.7$ & $12.4 \pm 1.5$ & $-8.5 \pm 7.4$ & NS \\
\hline Brown adipose tissue & 7 & $141 \pm 9.1$ & $120 \pm 11.7$ & $-15.5 \pm 5.2$ & $\mathrm{P}<0.05$ \\
\hline Liver** & 10 & $249 \pm 10.1$ & $214 \pm 8.6$ & $-14.1 \pm 2.6$ & $\mathrm{P}<0.001$ \\
\hline Diaphragm** & 10 & $146 \pm 6.3$ & $130 \pm 7.0$ & $-11.2 \pm 1.8$ & $\mathrm{P}<0.001$ \\
\hline
\end{tabular}

* $\mu \mathrm{l} \mathrm{O}_{2} / 100 \mathrm{mg}$ wet tissue/hr.

** $2 \mathrm{mM}$ palmitate was added into the incubation medium.

decreases respectively by the addition of vasopressin.

\section{DISCUSSION}

It has been reported by ARMSTRONG et $\mathrm{al}^{6}{ }^{6}$ that the turnover rate of plasma FFA is related in a quantitative manner to the prevailing plasma FFA concentration. Studies of Fine and Williams ${ }^{7)}$ and McElroy et al. ${ }^{8}$ have shown that the rate of FFA uptake by the liver depends on the FFA concentration of the blood circulating the organ. According to STEINBERG et al.9), calorigenic action of norepinephrine is causally related to its ability to increase the rate of FFA mobilization. In vitro experiments of EATON and STEINBERG ${ }^{10)}$ and of FRITZ et al. ${ }^{11}$ indicated that the rate of oxidation of FFA by isolated skeletal muscle preparation was a function of the concentration of FFA in the medium. Rose et al. ${ }^{12)}$ and NESTEL et al. ${ }^{13)}$ also reported similar effects of FFA concentration on FFA oxidation in rat liver slices and in perfused rat liver respectively. These observations may suggest that the decreased metabolic rate produced by vasopressin administration is primarily related to the decrease in the plasma FFA concentration. According to MIRSKY ${ }^{3-5}$, injection of vasopressin as well as oxytocin caused a significant decrease in the plasma concentration of FFA in the dog. In the present experiments a marked fall in the plasma FFA concentration was observed following vasopressin, but not following oxytocin, in the rat. The results are in accord with changes in the metabolic rate of rat injected with posterior pituitary hormone ${ }^{2)}$. In the rat oxytocin was less effective in decreasing the plasma FFA concentration. The discordance might be due to species differences in the response of adipose tissue to the hormone.

It was also shown that in vitro oxygen consumption by liver slices and hemidiaphragms is a function of the FFA concentration in the medium (FIGs. 1 and 2), confirming previous observations by other investigators ${ }^{10-13}$. How- 
ever, the decrease of in vitro oxygen consumption was roughly 20 per cent per $1 \mathrm{mM}$ palmitate in the incubation medium. As shown in TABLE 1, decrease in the plasma FFA concentration after injection of $100 \mathrm{mU}$ vasopressin was $264 \mu \mathrm{Eq} / 1$. This value is apparently too small to account for a 35.4 per cent decrease of the oxygen consumption under the same experimental conditions $^{2)}$. Therefore, the decrease in the metabolic rate produced by vasopressin may not solely depend on the lowered concentration of FFA in the plasma. It is well known that norepinephrine stimulates lipolysis, causing an increase in the plasma FFA concentration. The increment following subcutaneous injection norepinephrine in a dose of $200 \mu \mathrm{g}$ per $100 \mathrm{~g}$ body weight was 78.2 per cent, while rats treated with vasopressin showed only 16.7 per cent increase by the same dose of norepinephrine. As reported in our previous paper ${ }^{2}$, the increase in the oxygen consumption following norepinephrine was completely blocked by the pre-treatment with vasopressin. These findings clearly indicate that the inhibitory effect of vasopressin on the oxygen consumption is not merely attributable to the change in the plasma concentration of FFA. This inference will be supported by the fact that in vitro oxygen consumption of brown adipose tissue, liver and diaphragm was significantly suppressed by the addition of vasopressin, though that of epididymal adipose tissue was not affected significantly. The results together with our previous findings ${ }^{2}$ may suggest that the oxidation of FFA is inhibited in some way in the presence of excess vasopressin. Recently HoRowitz et al. ${ }^{17}$. reported that vasopressin inhibited both ${ }^{14} \mathrm{CO}_{2}$ production and lipogenesis from acetate $-1{ }^{-14} \mathrm{C}$. It was postulated by these authors that the hormone inhibits. the activation of acetate.

On the other hand, MIRSKY and PERISUTT ${ }^{18,19)}$ reported that oxytocin and related analogues of oxytocin exert an insulin-like action on the utilization of glucose by rat epididymal adipose tissue, stimulating the incorporation of labelled carbon into triglycerides. PitTman et al. ${ }^{20)}$ also found insulin-like activity of vasopressin and oxytocin on rat epididymal fat pads. According to CAHILL et al. ${ }^{21}$ and JUNGAS and BALL ${ }^{22)}$, incubation of rat epididymal fat pads in a medium added with epinephrine and insulin caused a marked increase in glycerol release, while FFA levels were reduced to very low values, indicating a rapid reesterification of FFA formed by lipolysis of tissue fat. If vasopressin exerts insulin-like action in promoting lipogenesis, as assumed by MiRsky and others, the hormone is expected to reduce FFA release by adipose tissue incubated in the presence of norepinephrine. It was, however, shown in the present study that vasopressin was ineffective to suppress the norepinephrine effect on the FFA release (TABLE 2).

Failure of vasopressin in stimulating the release of FFA is in accord with the result of RUDMAN et a1.23). They found that lysine vasopressin had no effect on the in vitro release of FFA by adipose tissue of the rat and 
hamster, though those of the rabbit and guinea pig responded to arginine vasopressin. On the other hand, VAUGHAN ${ }^{24)}$ claimed that Pitressin stimulated the release of glycerol and FFA by rat epididymal fat pads in vitro. However, it is difficult to evaluate her result, since her preparation of posterior pituitary hormone was not a pure vasopressin.

Explanation for the finding that vasopressin produced a decrease in the plasma FFA level without affecting the release of FFA should await further investigations.

\section{SUMMARY}

1. Effects of synthetic lysine vasopressin on the plasma concentration of FFA and in vitro oxygen consumption of tissues were studied in the rat.

2. The plasma FFA concentration decreased significantly following the injection of vasopressin, while the effect of oxytocin was less marked. Pre-treatment with vasopressin caused a significant suppression on norepinephrine effect in increasing the plasma FFA concentration.

3. In vitro oxygen consumption of liver slices and hemidiaphragms was related to the medium concentration of palmitate.

4. In vitro release of FFA by epididymal fat pads was not affected by the addition of vasopressin. FFA releasing effect of norepinephrine was not influenced by the presence of vasopressin.

5. In vitro oxygen consumption of brown adipose tissue, liver and diaphragm was significantly reduced by the addition of vasopressin into the incubation medium, while that of white adipose tissue was not affected by vasopressin. cation.

This investigation was supported by the research aid from the Ministry of Edu-

\section{REFERENCES}

1) OKuno, A., M. Yamamoto And S. Iтон: Lowering of the body temperature induced by vasopressin. Jap. J. Physiol. 15: 378, 1965.

2) Tsukada, M., A. Okuno And S. Itoh: Influence of vasopressin on the metabolic rate in rats. Jap. J. Physiol. $15:$ 388, 1965.

3) Mirsky, I. A.: Effect of oxytocin on plasma free fatty acids of non-diabetic and diabetic dogs. Proc. Soc. Exper. Biol. Med. 110: 42, 1962.

4) Mirsky, I.A.: Effect of oxytocin, vasopressin, and related peptides on plasma free fatty acids. Am. J. Physiol. 204: 842, 1963.

5) Mirsky, I. A.: Relative effects of insulin, oxytocin, and vasopressin on the free fatty acid concentration of the plasma of non-diabetic and diabetic dog. Endocrinology $73: 613,1963$.

6) Armstrong, D. T., R. Steele, N. Altszuler, A. Dunn, J.S. Bishop and R.C. DE BODo: Regulation of plasma free fatty acid turnover. Am. J. Physiol. 201: 9, 1961. 
7) Fine, M.B. ANd R.H. Williams: Effect of fasting, epinephrine and glucose and insulin on hepatic uptake of nonesterified fatty acids. Am. J. Physiol. 199: 403, 1960.

8) McElroy, W.T., Jr., W. L. Siefert and J. J. Spitzer: Relationship of hepatic uptake of free fatty acids to plasma concentration. Proc. Soc. Exper. Biol. Med. 104 : 20, 1960.

9) Steinberg, D., P. J. Nestel, E. R. Buskirk and R. H. Thompson: Calorigenic effect of norepinephrine correlated with plasma free fatty acid turnover and oxidation. J. Clin. Invest. 43 : 167, 1964.

10) Eaton, P. And D. Steinberg: Effects of medium fatty acid concentration, epinephrine, and glucose on palmitate-1-C14 oxidation and incorporation into neutral lipids by skeletal muscle in vitro. J. Lipid Res. 2: 376, 1961.

11) Fritz, I. B., D. G. Davis, R. H. Holtrop and H. Dundee: Fatty acid oxidation by skeletal muscle during rest and activity. Am. J. Physiol. 194: 379, 1958.

12) Rose, H., M. Vaughan and D. Steinberg: Utilization of fatty acids by rat. liver slices as a function of medium concentration. Am. J. Physiol. $206: 345,1964$.

13) Nestel, P.J. and D. Steinberg: Fate of palmitate and of linoleate perfused through the isolated rat liver at high concentration. J. Lipid Res. 4: 461, 1963.

14) Di Girolamo, M., D. Rudman, M. B. Reid and F. Seidman: Effect of pituitary hormones upon serum free fatty acid concentration of the rabbit. Endocrinology $68: 457,1961$.

15) Trout, D. L., E. H. Estes And S. J. Friedberg: Titration of free fatty acids of plasma: A study of current methods and a new modification. J. Lipid Res. 1 : 199, 1960.

16) Korn, E. D.: Clearing factor, a heparin-activated lipoprotein lipase. I. Isolation and characterization of the enzyme from normal rat heart. J. Biol. Chem $215: 1$, 1955.

17) Horowitz, I., D. Rubinstein And J.C. Beck: Inhibition of lipogenesis by vasopressin in vitro. 47th Meeting of Endocrine Soc. (U.S. A.) June 1965.

18) Mirsky, I. A. And G. Perisutti: The insulin-like action of oxytocin on adipose tissue. Biochim. Biophys. Acta 50:603, 1961.

19) Mirsky, I. A. And G. Perisutti: Action of oxytocin and related peptides on epididymal adipose tissue of the rat. Endocrinology 71: 158, 1962.

20) Pittman, J. A., B. R. Boshell, B. H. Williams, D. Hamner and P. Hill: Insulinlike activity of vasopressin and oxytocin. Biochem. Biophys. Res. Comm. 6: 29, 1961.

21) Cahill, G. P., Jr., B. Leboeuf and R.B. Flinn: Studies on rat adipose tissue in vitro. VI. Effect of epinephrine on glucose metabolism. J. Biol. Chem. 235: 1246, 1960.

22) Jungas, R. L. And E. G. Ball: Studies on the metabolism of adipose tissue. XII. The effects of insulin and epinephrine on free fatty acid and glycerol production in the presence and absence of glucose. Biochemistry 2: 383, 1963.

23) Rudman, D., S. J. Brown and M.F. Malkin: Adipokinetic actions of adrenocorticotropin, thyroid-stimulating hormone, vasopressin, $\alpha$ - and $\beta$-melanocyte-stimulating hormones, fraction $\mathrm{H}$, epinephrine and norepinephrine in the rabbit, guinea pig, hamster, rat, pig and dog. Endocrinology 72: 527, 1963.

24) Vaughan, M.: Effect of Pitressin on lipolysis and on phosphorylase activity in rat adipose tissue. Am. J. Physiol. $207:$ 1166, 1964. 